\title{
EFFECTIVENESS OF THE EXISTING HALAL LAWS IN MALAYSIA
}

\author{
Rokshana Shirin Asa ${ }^{1}$
}

\begin{abstract}
The disposition and consumption of halal food products are fundamental issues to be addressed in most Muslim states, especially where people of different religions live together. Laws are enacted in order to regulate and control halal food products. However, in the modern context, the implementation of halal certification laws has become very complex and challenging because of diversity. In view of this, the present study discusses the current amendments and the effectiveness of the existing halal certification laws in Malaysia. Generally, the discussion will be divided into two parts. The first part will explain the Trade Description Act (TDA) 2011 and orders related thereto, namely Trade Description (Definition of Halal) Order 2011, Trade Description (Certification and Marking of Halal) Order 2011 and the Trade Description (Certification and Marking of Halal Fees) Regulations 2011 between 1972 and 2011. The second part discusses the recent amendments from 2011 henceforth. The discussion also examines the power and functions of the Ministry of Domestic Trade, Cooperative and Consumerism (hereafter termed as MDTCC) and local authorities regarding the enforcement of halal laws and the implementation procedures used by Department of Islamic Development Malaysia (JAKIM)
\end{abstract}

\footnotetext{
$1 \quad$ Lecturer, Department of Law, Prime University, Dhaka 1216, Bangladesh, asha
} law@hotmail.com 
for halal certification. It also studies the limitations of JAKIM in its regulations to effectively control the misuse of halal logo and halal certification.

Keywords: halal certification, gradual development of halal laws, implementation, effectiveness of existing laws

\section{INTRODUCTION}

The last two decades have seen the emergence of halal industry as one of the fastest growing sectors. ${ }^{2}$ Malaysia entered the global halal food market by opening international restaurants in the 1970s. ${ }^{3}$ From the beginning, Muslim consumers have expressed their eagerness about imported halal food products. They demanded that all imported foods should be halal. That driving force encouraged the Malaysian authority to promulgate laws as well as specific rules and regulations on this matter. ${ }^{4}$ It paved the way for Malaysia to provide halal foods national and international jurisdiction which are highly recognized in the global market ${ }^{5}$. In Malaysia halal food and products have been industrialized in accordance with the tenets of Islamic laws. To that end, despite the complexity and challenges Malaysia can be a pioneer and role model for world's halal industries through the effective implementation of halal laws.

\section{Before the Amendment of TDA 2011}

The Trade Description Act (TDA) took effect on $3^{\text {rd }}$ November1972. The objectives of TDA 1972 are; to prohibit misdescription of food and goods, indicate the price of goods during the course of trade and business and forbid

2 Global Islamic Finance Report, 'The Global Halal Industry: An Overview,' http:// gifr.net/gifr2013/ch_13.PDF, accessed on 20 February 2015; Willy Adela Megan, 'The Edge Financial Daily,' http://www.theedgemarkets.com/article/malaysiaseen-potential- $\% \mathrm{E} 2 \% 80 \% 98$ halal-industry-champion $\% \mathrm{E} 2 \% 80 \% 99$, accessed on 7 March 2017.

3 Zannierah Syed Marzuki, S., Hall, C. M., \& Ballantine, P. W., 'Restaurant Manager and Halal Certification in Malaysia,' Journal of Foodservice Business Research, 15/2 (2012): 195-214.

4 Aziz, N. A., Ibrahim, I., \& Raof, N. A., 'The Need for Legal Intervention within the Halal Pharmaceutical Industry,' Procedia-Social and Behavioral Sciences (2014): 121, 124-132.

5 Muhammad, N. M. N., Isa, F. M., \& Kifli, B. C., 'Positioning Malaysia As HalalHub: Integration Role of Supply Chain Strategy and Halal Assurance System,' Asian Social Science, 5/7 (2009): 44. 
the creation of deceitful or misrepresentative statements of any services or goods. Due to the strong demands of consumers, the Malaysian government enacted two regulations under this Act, i.e. the Trade Description (Use of Expression Halal) Order 1975 and the Trade Description (Making of Food) Order 1975. At that time, the definition of halal was:

"When any food in any form used in relation to trade or business as or as part of, trade description applied to the food, the expression "Halal", "Di-tanggong Halal" or "Makanan Islam" or any other expression indicating or likely to be understood as indicating that Muslims are permitted by their religion to consume such food such expression shall have the following meaning-

(a) neither is nor consist of or contains any part or matter of an animal that a Muslim is prohibited by Hukum Syarak to consume or that has not been slaughtered in accordance with Hukum Syarak;

(b) does not contain anything which is considered to be impure according to Hukum Syarak;

(c) has not been prepared, processed or manufactured using any instrument that is not free from anything impure according to Hukum Syarak; and

(d) has not in the course of preparation, processing or storage been in contact with or close proximity to any food that fails to satisfy paragraphs (a), (b) or (c) or anything that is considered to be impure according to Hukum Syarak"

The Ministry which governed the TDA, 1972 was the Ministry of Domestic Trade and Consumer Affairs (MDTCA) which is now known as Ministry of Domestic Trade, Cooperative and Consumerism (MDTCC). Nevertheless, with the 1972 Act, there were some problems which did not effectively regulate the halal issues. The main problem is the absence of a comprehensive definition of halal. At that time, the halal definition was restricted in terms of food only. Other problems were absence of specific provision of exercise of jurisdiction, who was designated to handle halal matters and which authority had to issue the halal certificate. Then, the Trade Descriptions (Use of Expression Halal) Order 1975 had empowered some persons and private companies to issue halal certificate and halal logo. This is because the order did not mention the name of any definite authority that was authorized to issue halal certificate and halal logo. The abovementioned laws have been applied for a long time but there 
are several lacunas in terms of effective implementation that was evidently shown in the report of MDTCC, regarding fraud or abuse cases of halal logo and halal certificate. ${ }^{6}$

\section{Post-Amendment of TDA 2011}

After 39 years of this Act, in 2011, the Malaysian legislators amended the TDA and it was enforced on $1^{\text {st }}$ November of the same year. Along with the by-laws, namely Trade Description (Use of Expression Halal) Order 1975 and the Trade Description (Halal Labeling) Order 1975 were also restructured and added with more orders such as the Trade Description (Definition of Halal) Order 2011, and Trade Description (Certification and Marking of Halal) Order 2011 and Trade Description (Certification and Marking of Halal Fees) Regulations 2011. The objectives of these TDA, 2011 are to insert some provisions and reform the loopholes in the laws regarding trade and halal. There are numerous sections that have been added, for instance, Sections 9 (1 and 2), 16, 20, 23, 32 and in the case of halal regulations the most important introduction are Sections 28, 29 (Trade Description Act, 2011). The new amendment Act 2011, like its predecessor, promotes good trade practices and prohibits false trade, statements and conduct in relation to goods and services. The most noteworthy feature of this amendment is the introduction of the Trade Description (Definition of Halal) Order 2011, the Trade Description (Certification and Marking of Halal) Order 2011 and Trade Description (Halal Certification and Marking Fees) Order 2011 that provide specific legal provisions on matters related to halal. These three by-laws were enforced on $1^{\text {st }}$ January 2012.

Section 3 of Trade Description (Definition of Halal) Order 2011 provides the definition of halal regarding food, goods or services in the course of trade or business or by any other means which indicate that Muslims are allowed to eat such food.

"The food, goods and services for which halal is applied that:

(a) does not consist of or contain any part or matter of an animal that a Muslim is prohibited from consuming or has not been slaughtered in accordance with Shariah and fatwa;

(b) does not contain anything impure according to Shariah and fatwa;

$6 \quad$ Che Omar, C. M. Z., 'Challenges and Marketing Strategies of Halal Products in Malaysia,' Interdisciplinary Journal of Research in Business, 3/2 (2013): 11-17. 
(c) does not intoxicate according to Shariah and fatwa;

(d) does not contain any part of a human being or its yield which is not allowed by Shariah and fatwa;

(e) is safe to be used or consumed, not poisonous or hazardous to the health;

(f) has not been prepared, processed or manufactured using any instrument that is not free from anything impure according to Shariah;

(g) has not in the course of preparation, processing or storage been in contact with, mixed, or in close proximity to any food that fails to satisfy paragraphs (a) and (b)".

Moreover, the Trade Description (Certification and Marking of Halal) Order, 2011 also mentions the competent authority. According to Section 2(1) of the said Order, competent authority includes JAKIM and the State Islamic Religious Council. These two authorities can certify food, goods and services as halal under this order. Any food, goods and services shall not be conferred halal certification unless the abovementioned authorities certify it as halal. Therefore, when the certification is completed and satisfied by the competent authority, then halal certificates or halal logo can be used on food, goods and services. If any food, goods and services are certified by any other persons or authorities other than JAKIM and State Islamic Religious Council the certification shall be void. ${ }^{7}$ As mentioned earlier, before the amendment of this Order, 2011 came into being there were several bodies or private agencies that issued halal certificate. By virtue of TDA Act 2011, MDTCC was empowered to give explanation to any expression and description used in any food, goods and services. ${ }^{8}$ Regulating the issuance of halal certification is the main purpose of this amended Act, 2011. Aside from that, TDO 2011 also provides guideline of penalty against criminal acts. For instances, if any offence is committed by a corporation, it is liable to a fine not more than RM5 million and not more than RM10 million for the next or succeeding offences. ${ }^{9}$ In addition, if the offence is committed by an individual then the fine is not more than RM1 million and for the next or succeeding offence, the fine does not exceed RM5 million or imprisonment, not more than five years, or both. ${ }^{10}$ On the other hand, TDO

\footnotetext{
S 2(2) of Trade Description (Certification and Marking of Halal) Order 2011.

S 28 of Trade Description Act, 2011.

9 S 7 of Trade Description (Definition of Halal) Order, 2011.

10 S 7 of Trade Description (Definition of Halal) Order 2011.
} 
gives power to MDTCC to receive official complaints from business owner before necessary action is taken to stop any offence in the case of false trade description. ${ }^{11}$

Though TDA 2011 does not directly mention any provision regarding halal, Sections 28 and 29 of this said Act have conferred power to the minister to make orders and regulations for effective halal enforcement. For instance, Trade Description (Definition of 'Halal') Order 2011 provides definition of halal, service in relation to food and goods along with punishments for offence for deceitful or misleading use of halal. Apart from that Trade Descriptions (Certification and Marking of 'Halal') Order 2011, defines halal certification and delivers power to JAKIM and State Islamic Religious Council as competent authorities for issuing uniform halal logo for Malaysian food and goods. However the abovementioned order considers JAKIM and State Islamic Religious Council as component authority but general practice shows neither JAKIM nor State Islamic Religious Council is party to infringement case of those Act and Orders. In all cases, MDTCC is the main party. Furthermore, application of this law and orders is only limited to the traders, manufacturers or producers whose food or goods contain halal mark. Nevertheless, law and orders do not impose an obligation that all food and goods use the halal mark. As a result, until today Muslim consumers' right to get halal food is not strictly guaranteed.

\section{METHODOLOGY}

The research methodology chosen for this article is qualitative in nature relying on both primary and secondary sources. The primary sources include statutes related to halal certification in Malaysia, while the secondary sources comprise of library materials (textbooks, journal articles, and newspapers), internet resources (i.e. online databases) and annual reports of JAKIM and MDTCC.

\section{HISTORY OF THE ESTABLISHMENT OF THE HALAL RELATED AGENCIES}

\section{The Ministry of Domestic Trade, Cooperative and Consumerism}

Previously, this Ministry was known as the Ministry of Domestic Trade and Consumer Affairs (MDTCA), which was established on $27^{\text {th }}$ October 1990.

11 S 6 of Trade Description (Definition of Halal) Order 2011. 
At the beginning, it was assigned to govern TDA. This power is delegated by the previous and amended TDA 2011. The aim of this Ministry is to promote good trade practices and protect consumers' rights. In 2009, it expanded its power and function to cover the license and cooperative sectors, which enhanced its jurisdiction. ${ }^{12}$ The main function of MDTCC is to frame policies and strategies and review matters related to the development of domestic trade and consumerism. Apart from that, the working jurisdiction of the MDTCC is related to domestic trade, co-operative and consumerism that are presented in Figure 1:

Figure 1: Working Jurisdiction of the MDTCC

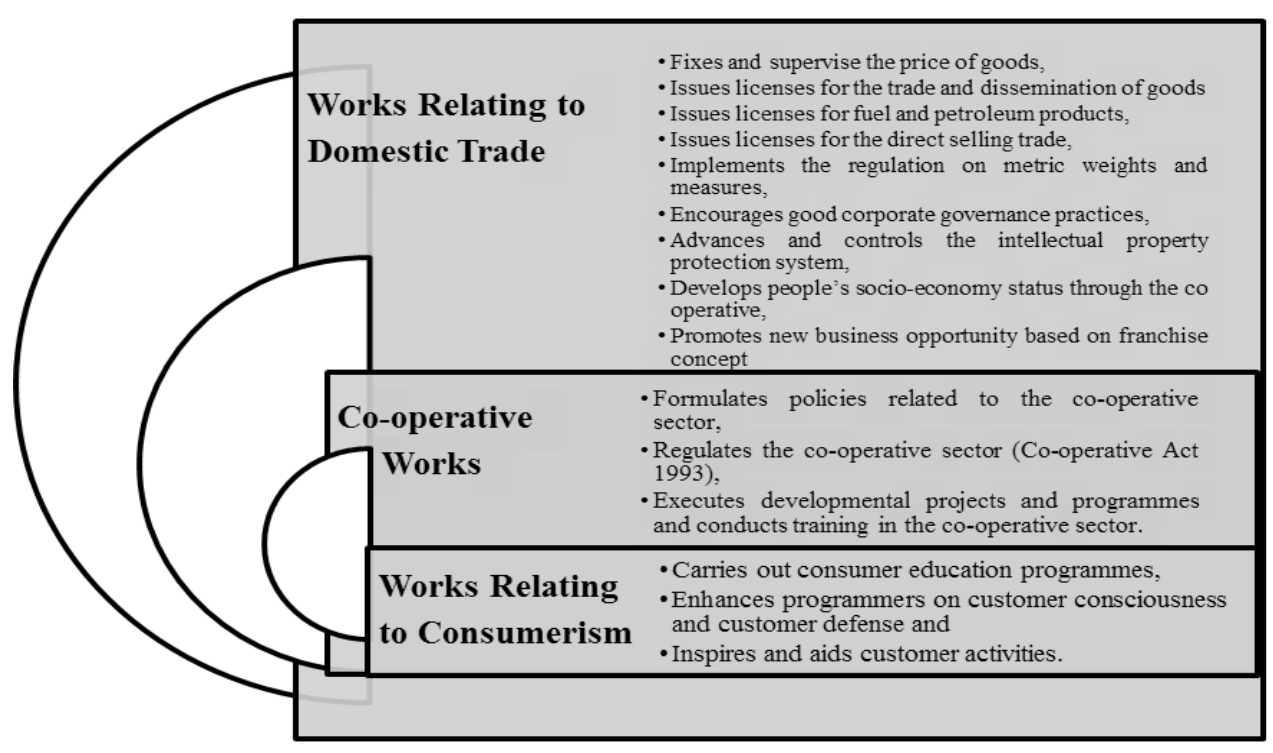

Source: Official Portal of Ministry of Domestic Trade and Consumer Affairs ${ }^{13}$

In achieving vision 2020 of Malaysia, this Ministry has been working to ensure domestic trade centers on a high-income economy with fair competition

12 Ministry of Domestic Trade, Cooperatives and Consumerism, 'The Ministry Establishment,' http://www.kpdnkk.gov.my/index.php/en/mdtcc/profile/backgrou nd, para 1, accessed on 19 February 2015.

13 Ministry of Domestic Trade and Consumer Affairs, 'Background Information,' Official Portal of Ministry of Domestic Trade and Consumer Affairs, http://www. kpdnkk.gov.my, accessed on 10 October 2015. 
and innovation and develop an internal bio-network based on moral values and consumer consecration. That is clearly cited in its mission. ${ }^{14}$

In Malaysia, every ministry has its own priority and strategic trust. For MDTCC, there are five strategic thrusts, which are enrich involvement of the domestic trade sector towards gross domestic product (hereafter termed as GDP), create competent consumer society and ethical business practices, nurture innovation-based economy by virtue of effective legal system, enhance societal well-being and create excellent organization. Together with, the Ministry has some policies also. To achieve their strategic thrusts, there are 33 Acts under the supervision of MDTCC, CCM, MyIPO, MKM, SKM, Bank Rakyat and MyCC, including Trade Description Act 2011, that relate to halal enforcement. ${ }^{15}$

As stated before, by studying MDTCC's entire objectives, working jurisdictions, policies, five strategy trusts and most importantly Acts, we can see that there are some problems in terms of enforcement of activities regarding halal matters. First of all, their policy, as well as the five strategic thrusts on 'halal' is not the priority. Moreover, under the MDTCC, there are 2,000 employees who are not allowed to take leave frequently because they have to enforce price control to determine whether traders are selling items at the allowed price or not. Between September 2011 to September 2015, the enforcement divisions of MDTCC and JAKIM have filed 120 cases on abuse of halal logo. Out of this 120 cases 64 cases are almost settled and the rest 56 pending jurisdiction. ${ }^{16}$

To date, there are 33 different Acts under the preview of MDTCC but it has very limited number of enforcement officer; they do not have enough time to carry out the enforcement of each Act. Too many Acts have weakened their enforcement power as well. Besides, the statistics report of enforcement activities implemented by MDTCC for 2010-2013 include food but without the halal status, on pharmaceuticals, cosmetics, cigarettes and liquor/beer. ${ }^{17}$

\footnotetext{
14 Ministry of Domestic Trade, Cooperatives and Consumerism, 'Ministry Profile,' http://www.kpdnkk.gov.my, accessed on 21 February 2015.

15 Ministry of Domestic Trade, Cooperatives and Consumerism, 'Minister's Strategic Thrusts,' http://www.kpdnkk.gov.my, para 1, accessed on 23 February 2015.

16 Othman Nawang (Deputy Director of Enforcement Division, Ministry of Domestic Trade, Cooperatives and Consumerism), in interview with author, 5 October 2015.

17 Ministry of Domestic Trade, Cooperatives and Consumerism, 'Main Statistic of Enforcement 2010-2013,' http://www. kpdnkk.gov.my, accessed on 23 February 2015.
} 
Therefore, from the above discussion, it is apparent that though Malaysia having its own halal regulations but some problems still exists in its enforcement execution.

\section{Movement of JAKIM}

One of the main federal government's religious agencies in Malaysia is JAKIM. The development of Islamic affairs recorded in Malaysia is based on the Federal Constitution. According to Article 3 of the Federal Constitution of Malaysia (2009), Islam is the religion of the federation. In light of that, both the Federal and State governments have been empowered to recognize the Islamic law.

Since JAKIM's establishment in 1968, it has played an important role in the development of Islamic affairs together with the development of Muslim communities ${ }^{18}$ Consequently, on $17^{\text {th }}$ October 1968 , the $81^{\text {st }}$ Malaysian Council of Rulers decided that a body that co-ordinates Islamic affairs in Malaysia is needed. On $1^{\text {st }}$ July 1969, the National Council for Islamic Affairs Malaysia was officially established. Concurrently, a secretariat was formed that became the Religious Division. Later it was renamed Islamic Affairs Division or Bahagian Hal Ehwal Islam (hereafter termed as BAHEIS). ${ }^{19}$ In 1970, the Secretariat of the National Council for Islamic Religious Affairs of Malaysia carried out its duties for the physical development of Islamic centers. It established the Islamic Research Centre (PPI) in 1971 and the Islamic Da'wah and Training Institute (hereafter termed as INDAH) in 1974. Afterwards, its obligations and accountabilities increased and became much more challenging. In 1974, it started to involve itself in the confirmation of halal regarding consumers' supplies and products. ${ }^{20}$ During that time, the Islamic Research Centre along with the Office of the Prime Minister started issuing halal certification for products that comply with the rules. ${ }^{21}$

In the first ten years (1970-1080), the National Council for Islamic Religious Affairs of Malaysia arranged for more than 20 conferences and

18 Department of Islamic Development Malaysia, 'About JAKIM,' http://www. islam.gov.my/en/about-jakim, accessed on 24 February 2015.

19 Department of Islamic Development Malaysia, 'History of JAKIM,' http://www. islam.gov.my/en/about-jakim/jakim-s-profile/history, para 3, accessed on 27 February 2015.

20 Department of Islamic Development Malaysia, 'History of JAKIM.'

21 Department of Islamic Development Malaysia, 'History of JAKIM.' 
nearly 200 general Islamic issues were debated; in the end, numerous issues were discussed and resolved. The Religious Division of the Prime Minister's Department was re-structured and extended again in 1984 and advanced its current position. On $21^{\text {st }}$ May 1985, the Religious Division was re-named the Islamic Affairs Division, Prime Minister's Department. At the beginning of 1994, in a more structured way, it came up with a halal logo and halal certification by the Food and Consumer Goods Unit (under the Research Division, Islamic Affairs Division). Furthermore, the government of Malaysia improved BAHEIS by taking over its role and posting it under a new name: the Department of Islamic Development Malaysia (JAKIM) on $1^{\text {st } J a n u a r y ~} 1997$.

One year later in 1998, a company called Irham Daya was authorized by the government to carry out the inspection of halal products, then the government instructed JAKIM's Food and Islamic Consumer Products Division to conduct all activities related to halal certification on $1^{\text {st }}$ September 2002. On $17^{\text {th }}$ November 2005, the Malaysian government created Halal Hub Division to ensure the needs of the Muslim population are protected and to cope with the rapid development of the food industry in the country. This is also known as food and consumer goods for Halal Hub Division. Then, the halal certification activity was officially handed to the Halal Industry Development Corporation (hereafter termed as HDC) on $2^{\text {nd }}$ April 2008. ${ }^{22}$ The government was not satisfied with the activities of HDC regarding halal certificate thus for the second time, the cabinet meeting on $8^{\text {th }}$ July 2009 conferred halal certification activities to JAKIM. Finally, Section 2(2) of the Trade Description (Certification and Marking of Halal) Order 2011 (Amendment) named JAKIM as the "competent authority" alongside JAIN/MAIN.

Based on the explanation of the objective of JAKIM, it is clear that its work relates to the effective and efficient development of Islamic affairs such as extensive teachings of Islam, developing an ethic based, creating a trained, competent, dedicated and wise leadership and management system that resulted in a managing team. In addition, its other functions are indicated in Figure 2:

22 Halal Hub Division of JAKIM, 'Halal History,' http://www.halal.gov.my, accessed on 27 February 2015. 
Figure 2: JAKIM's Functions

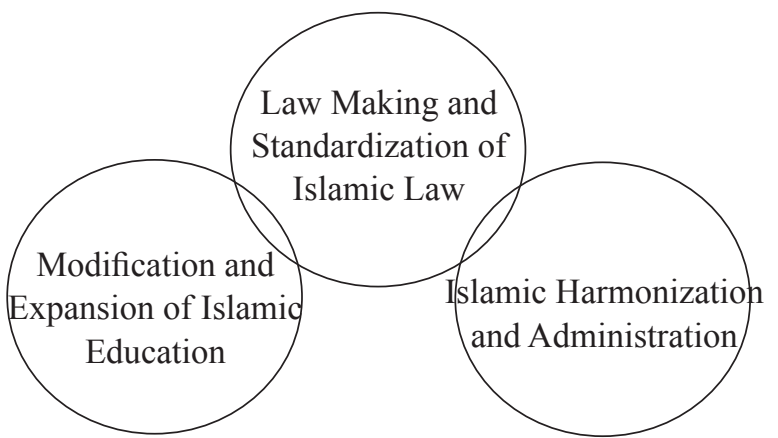

Source: Department of Islamic Development Malaysia ${ }^{23}$

Emphasis on its first function relates to legislation and standardization of Islamic law, thus it concentrates only on streamlining and implementing the directives of the Council of Rulers on Islamic matters; enacting legislations, reviewing and amending Islamic laws for standardization amongst the Federal territories as well as stating and updating fatwa and implementation of compliance. $^{24}$

Apart from that, its second function is achieving Islamic harmonization and administration through many activities, some relate to controlling the faith of deviated groups that threaten national security; planning administration policies and Islamic affairs management based on the provision in the Federal Constitution; leading research efforts on current issues in the fields of faith, Islamic law, astronomy and finance at the national, regional and international levels; becoming the main monitoring agency in Islamic law compliance of various Islamic products and services and consumerism, specifically in the fields of Islamic financial systems and halal industry and so on. Moreover, their third function includes modifying and advancing of Islamic education by selecting a group of experts in many areas of Islamic knowledge; creating Malaysia as the hub for higher learning at the local and international levels and researching on al-Qur'ān and hadìth; progressing and updating Islamic education and administration of nationwide religious schools, etc.

23 Department of Islamic Development Malaysia, 'The Role of JAKIM,' http//www. islam.gov.my, accessed on 15 October 2015.

24 Department of Islamic Development Malaysia, 'Vision, Mission, Objectives, Functions,' http://www.islam.gov.my/en/about-jakim/vision-mission-objectivesfunctions, accessed 02 March 2015. 


\section{Activities of Halal Hub Division}

Based on the previous information, the Public Service Department of Malaysia created Halal Hub Division on $17^{\text {th }}$ November 2005 due to the rapid development of the food industry in Malaysia to fulfil the needs of the Muslim population. From that time, halal certification has been conducted by the Division of Halal $\mathrm{Hub}$ that is one of the significant divisions of JAKIM. ${ }^{25}$

Its main task is to guarantee that the products which are authorized or certified as halal are genuinely halal in compliance with the Shariah principles. To do so, a recognized halal certification center which is acknowledged nationally and internationally must be established. All food and products that are necessary for Muslims are examined, certified and regulated by the Halal Hub Division so as to assure wholesomeness and only then halal certification is given in conformity with Islamic principles. ${ }^{26}$

However, the Halal Hub Division emphasizes on halal certification as it has its own manual to regulate the halal certification process which is called the Malaysian Halal Certification Procedures Manual (hereafter termed as MPPHM) to be used together with the Malaysian halal standard. It contains application procedures, conditions and requirements, certification process, the rate of fees regarding halal certification, etc. In 2005, the manual was first published but it was revised in 2011 to ensure better services. ${ }^{27}$ The manual was revised for the third time in 2014 to coordinate with the Guidelines on Halal Assurance System Malaysia 2011 (JHM, 2011) and the announcement of the implementation of the Halal Assurance System. The objective of a more recent revision in 2014 was to improve and restructure the certification requirements. It became effective on $15^{\text {th }}$ December $2014 .^{28}$

The 2014 MPPHM consists of the definition of halal and any other related terms, certification requirements, general requirements of certification, application procedure according to the scheme, auditing procedure, monitoring and enforcement and condition of use of Malaysian halal certificate and halal logo. Apart from that, auditing, monitoring and enforcement are significant activities of Halal Hub Division. In the case of halal certification, auditing is the most vital because the auditing halal penal/body will decide whether halal

\footnotetext{
25 Department of Islamic Development Malaysia, 'History of JAKIM.'

26 Nor Ain Musa, 'A Study on Muslim Consumers' Awareness on JAKIM Halal Logo,' (PhD Dissertation, Faculty of Engineering Technology, Universiti Malaysia Pahang, 2013).

27 The Halal Malaysian Certification Procedure Manual, 2014.

28 Malaysian Halal Certification Procedure Manual, 2014 (Circular No 2) (Malay.)
} 
certification shall be given or not. The manual then specifies the monitoring and enforcement of the TDA 2011 with other Acts for example, Malaysia Halal Certification Procedures Manual 2011 (Second Revision), Food Act 1983 (Act 281), Food Regulations 1985, Food Hygiene Regulations 2009, Animals Act 1953 (Revised 2006), Animal Regulations 1962, the Abattoirs (Privatization) Act 1993, National Livestock Development Board (Dissolution) Act 1983, Customs Act 1967 (Prohibition of Imports 1998), Local Government Act 1976 (Act 171) and By-Laws of Local Authorities (LAs), Act/Administration of Religious Affairs and Trade Marks Act 1976 (Halal Malaysian Certification Procedure Manual, 2014). So, all inspection on monitoring and enforcement should be done based on the manual 2014.

On the other hand, the inspection shall be of different types, namely periodic inspection, follow-up inspection and inspection based on a complaint made by the public. In the case of periodic inspection, it will be time to time inspection to examine that certificate holders are complying with the conditions and standards of Malaysian halal certification and halal logo. Furthermore, inspection based on previous examinations of the companies that fail to comply with halal certification procedure is called follow-up inspection and if any complaint is made by the public or an individual about the misuse of logo and halal certification or there are doubts about the products, goods, eateries, slaughterhouses, logistics or companies that have been provided halal certification, halal logo or use the expression then it is known as inspection based on a complaint made by the public. After the inspection, inspectors will leave a copy of the notice to the company. ${ }^{29}$ Any offences noted after the monitoring inspection are categorized into 3 stages as shown in Figure 3:

Figure 3: Different Type of Offences

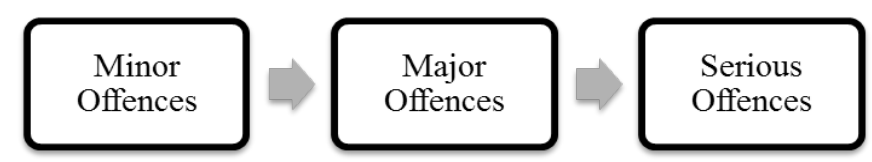

Source: Manual Procedure for Malaysia Halal Certification ${ }^{30}$

A minor offence includes the things such as premise cleanliness; equipment cleanliness, surrounding cleanliness and pest control; failure to show the

\footnotetext{
29 Art. 10.2 of Malaysian Halal Certification Procedure Manual, 2014.

30 Department of Islamic Development Malaysia, 'Manual Procedure for Malaysia Halal Certification (Third Revision) 2014,' Halal Malaysia Official Portal, http:// www.halal.gov.my, accessed on 20 October 2015.
} 
related documents and the changing of supplier or producer who obtain halal certification to another without any permission by JAKIM, etc. These conditions warrant warning or reminder given by the officer. On the other hand, major offences are any technical offences which include the changing of supplier or producer who did not obtain halal certification from recognized Islamic bodies; the use of JAKIM halal logo on a product not listed in the JAKIM halal certificate; misuse of JAKIM halal certificate; giving lease of halal certificate to other premise or company; owning and exhibiting an expired halal certificate and failure to comply with the instruction of correction due to minor offences. Actions for the above cases include a withdrawal of JAKIM halal certification and this will be presented to the halal certification panel meeting for the final decision. Furthermore, serious offences are any technical and Shariah offences for which action to be taken is a withdrawal of JAKIM halal certificate and thus will be presented to the halal certification panel meeting for the final decision. It is classified as technical and Shariah offences. Technical offences include:

a) Non-halal material in the premise or company which has JAKIM halal certificate.

b) Putting the unclean and clean products in one area.

Shariah offences are:

a) Usage of non-halal materials after obtaining by JAKIM halal certificate;

b) Using halal with non-halal equipment.

As per Manual 2014, in the matter of prosecution, it will be carried out either by the Ministry of Domestic Trade, Cooperative and Consumerism Ministry or other law enforcement agencies based on input from JAKIM/MAIN/JAIN about halal matters. ${ }^{31}$ They will be called as witnesses in the court case for the matter. The brief discussions on monitoring and enforcement initiates taken by Halal Hub Division in the case of halal certification enforcement given above are evident in Manual 2014.

In summary, the role of JAKIM can be understood as a body established for the development of Islamic affairs and Islamic communities. In the middle of 1968 to 2011 the organizational structure as well as the administrative activities had been changed to strengthen the power and functions of JAKIM. That is to say, the government tried to make it more effective and efficient in terms of its structure and activities. At the beginning, its concentration did

31 Art.10.6 of Malaysian Halal Certification Procedure Manual, 2014. 
not relate to halal issues. The establishment of the Islamic Research Center in 1974 was for halal issues, but the development was very slow compared with the development of its organizational structure. Since its establishment, halal issue did not get the attention as others did. Very gradually it came under the jurisdiction of JAKIM.

Between 1979 and 1989, the National Council for Islamic Religious Departments of Malaysia carried out many activities that did not relate to halal matters. At the initial period of 1994, JAKIM came up with a halal logo and halal certification that were remarkable achievements in terms of halal execution. After that, the Malaysia government enhanced BAHEIS and transferred it to JAKIM on 1st January 1997. In time, halal certification charges were acceptable but four years later, unfortunately, the government handed it over to one private company called Irham Daya; which charges higher costs for getting halal certification as the idea was to commercialize the process by 1998. But it did not go down well, thus the task went back to JAKIM in 2002.

In conclusion, the halal certification process and other matters related to the issue have been passed from one establishment to another, yet no one seemed able to handle it properly. The matter was no longer under the dominion of JAKIM solely. Several times it was given to JAKIM but it was taken over later by others. In 2005 it was handed over to Halal Hub Division and again in 2008 it came back to HDC; finally, in 2011 because of the amendment of TDA it was given to JAKIM. Thus, all of these are glitches regarding the organizational outlook on which authority will govern the halal issues. During these ups and downs, nobody was particularly concerned about its effective execution. Based on the history it may be seen that everyone took halal implementation very lightly.

Looking back into the objectives of JAKIM, all of its activities relate to the expansion of Islamic teachings, management system, training and so on. None of their objective or function relates to halal activities. Though the establishment of one division called Halal Hub Division halal matters were incorporated into their activities. Nevertheless, regarding halal certification, it should go under the purview of JAKIM. Apart from that, for administrative purposes, JAKIM has some laws together with its own halal manual. In the manual, JAKIM is authorized to do auditing and inspecting. The Manual also gives it the power to exercise its enforcement with MDTCC. On the other hand, these are the main limitations of JAKIM to successfully execute matters concerning halal issues.

Although JAKIM officials conduct their inspection in different ways, they can only leave their notice, suspend, withdraw or postpone the certification 
for the time being. In very few exceptions, they impose charges as a penalty. JAKIM has prosecution power but only function as a witness in the court. Till now, for abuse of halal certification or fake logo, the party to the cases is MDTCC, not JAKIM. Though it seems that JAKIM has all the power, the main power in terms of effective enforcement is still in question. Not exercising its enforcement power appropriately makes its future defenseless. In view of that, it needs a special power to govern all the halal issues to avoid cases of abuse of halal certification and halal logo that can make its position stronger. Enforcement of laws is not possible without giving any power to exercise it accurately. That is also admitted by one of the members of JAKIM's Halal Hub Division. They are also seeking more enforcement power for effective implementation of halal issues. ${ }^{32}$

\section{LOCAL GOVERNMENT ACT AND HALAL ISSUES}

Every government has its own organizational structure in regulating the activities of the state. This is called the hierarchy of the organization. The local government of Malaysia is the last group of the hierarchy of government, after the federal and the state. The status of the local government in Malaysia is declared in the Federal Constitution. ${ }^{33}$ Under the Federal Constitution, local governments are under the special dominion of the state government along with those that are the subjects in the federal territories (KL, Labuan and Putrajaya); this is clear from the state list (Ninth schedule of the Federal Constitution of Malaysia, as amended, 1988).

The local government of Malaysia started its activities through the power given by the Local Government Act 1976 (Act No 171) to distribute goods and services to local individuals. On $18^{\text {th }}$ July 1978 , it was renamed the Ministry of Housing and Local Government. That was the unification between the Ministry of Housing and Rural Development and the Department of Local Government. Previously, it was part of the Ministry of Local Government and the Federal Territory. In Malaysia, by hierarchy, the city council is the uppermost authority and the district council is the lowermost authority. There are 12 city councils, 39 municipal councils, 98 district councils and five special and modified local authorities. Act 1976 provides for some obligatory and discretionary functions

32 Mohd. Amri Abdullah (Senior Assistant Director, Halal Hub Division, Department of Islamic Development Malaysia), in personal communication with author, 13 February 2015.

33 Ministry of Urban Wellbeing, Housing and Local Government, 'About MHLG,' http://www.kpkt.gov.my/, accessed on 22 March 2015. 
for the development of the local people. For obligatory functions, it does the activities shown in Figure 4:

Figure 4: Functions of the Local Government

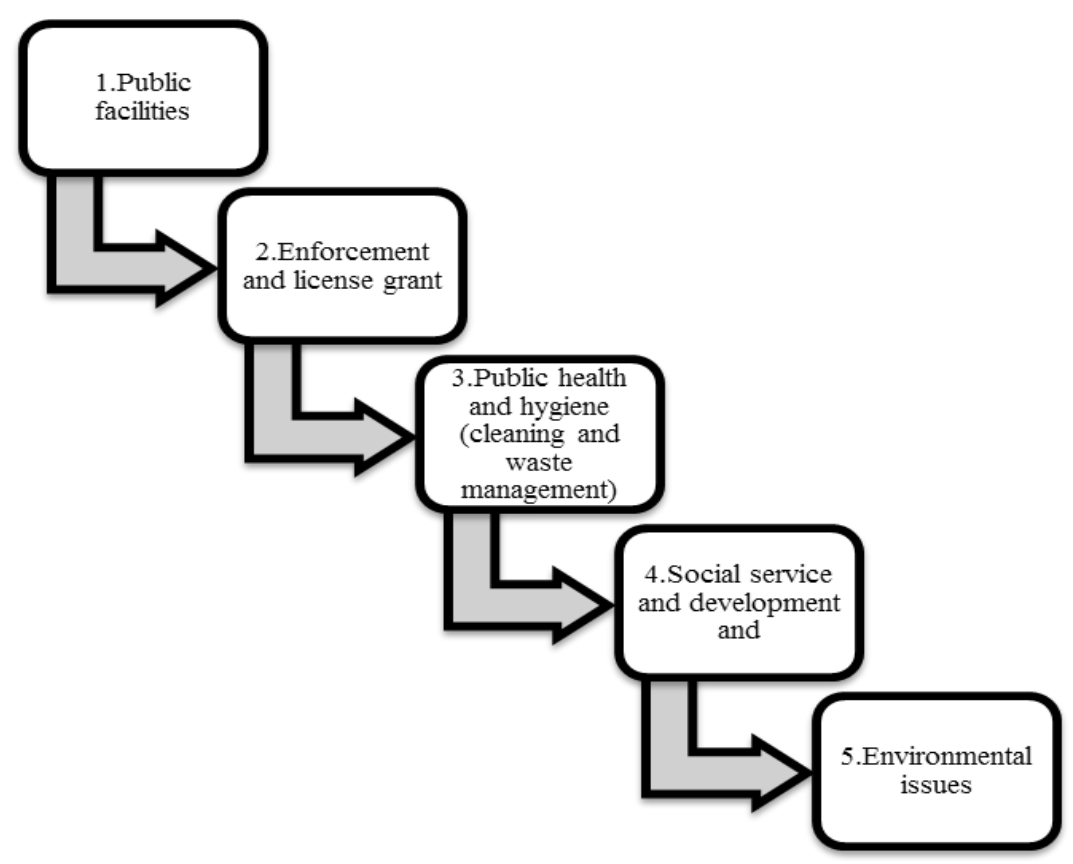

Source: Official Portal of Ministry of Housing and Local Government ${ }^{34}$

The local government's policies, strategic thrust, guidelines and legislation, all of their activities are for the effective execution of the local development. The objective of the Local Government Act is to ensure uniformity of laws and policies with respect to the local government. For that reason, this authority regulates the Local Government Act 1976 as well as some by-laws, for instance, advertisement by-laws, food handlers' by-laws, food establishment by-laws, etc. ${ }^{35}$

As stated earlier, besides JAKIM, MDTCC and the local government authorities are authorized to ensure halal execution. Under the Local Government Act, there are numerous sections that have given the halal execution power to

34 Ministry of Housing and Local Government, 'KPKT Client Charter,' Official Portal of Ministry of Housing and Local Government, http://www.kpkt.gov.my/, accessed on 20 November 2015.

35 Ministry of Urban Wellbeing, Housing and Local Government, 'About MHLG,' http://www.kpkt.gov.my/, accessed on 22 March 2015. 
the local authority. In Act 1976, there is no 'halal' word but it is applicable in the same manner as other executions. If any power exercises control over any offence related to food then the same application will be followed in the case of halal food. Additionally, if any offence is committed in the case of advertisement the same procedure is followed by halal advertisement. In the following sections, it will be evident that local governments have more power than JAKIM to take action against any wrongdoing related to halal.

According to Section 73 of Local Government Act 1976, in case of food handling, local authority has the power:

"(i) to regulate, control, inspect and supervise the manufacture, preparation, storage, handling, transmission and conveyance of any article of food or drink or of ice which is for sale;

(iii) to prohibit the introduction into the local authority area, the possession, sale or offering for sale for the purpose of human consumption or the handling other than for the purpose of destruction, of diseased animals, birds, meat or fish or of fruits, vegetables or other articles of food or drink which are unsound, unwholesome or otherwise unfit for human consumption;

(iv) to authorize the seizure, inspection and examination and to ensure the destruction

(e) to regulate the slaughtering of animals and to provide for the establishment, control, supervision and inspection of abattoirs within the local authority;

(vii) the prohibition, except with a permit granted by the local authority, of the introduction into the local authority area for human consumption of the meat of any animal slaughtered outside the local authority area;

(viii) the entry by any authorized officer of the local authority by day or night into any premises in which he has reason to believe that any animal is likely to be or has been slaughtered in contravention of the provisions of any by-laws".

Furthermore, Section 101 of the Local Government Act, 1976 states, in case of execution of power, the local authority shall have the power to do all or any of the following things:

“(v) to do all things necessary for or conducive to the public safety, health and convenience; 
(cc) (ii) to remove any dilapidated fence or structure abutting upon any public place and if such owner or occupier fails to comply with any such request any authorized officer of the local authority may enter upon the said premises and carry out such work and section 115 shall apply to the expenses incurred thereby;

(ff) to do all things necessary for carrying out all the provisions for and in regard to which the local authority is empowered from time to time to make by-laws, standing orders, rules and regulations, and for carrying out all such by-laws, standing orders, rules and regulations into effect".

Along with this, in case of advertisement, local authority shall have the power to do all or any of the following things:

“(c) to regulate, license, restrict, prevent or remove the exhibition of advertisements" (Local Government Act 1976 s102).

The aforesaid sections are the main driving principles of local authority. For the enforcement of the Local Government Act, each local authority has the right to enact by-laws in their own territory. For that reason, every local authority has by-laws such as:

a) Shah Alam City Council has 16 by-laws including: Food Establishment Laws 2007, Laws and Advertising 2007, Laws and Food Handlers 2007, etc.

b) Petaling Jaya City Council has 9 by-laws including: Advertisement by-laws (MBPJ) 2007, Food Establishment Licensing by-laws (MBPJ) 2007, Food Supervisor by-laws (MBPJ) 2007, Trade, Business and Industrial by-laws (MBPJ) 2007, etc. (By Laws, 2013)

For example, Section 6 of the Shah Alam City Council by-laws contains the provision of usage of halal signage. If any person uses the word, logo or halal or be certified halal signage without a certificate of halal issued by the Islamic Development Department of Malaysia, the Selangor Islamic Council or any other relevant authority he/she shall be guilty of an offence and shall upon conviction be liable to a fine not exceeding two thousand ringgit or to imprisonment not exceeding one year or both. The licensing authority may inspect the authenticity and validity of the aforesaid certificate and any person who fails to produce the certificate upon request made by the licensing authority shall be guilty of an offence. ${ }^{36}$

36 Advertisement (Shah Alam City Council) By-Laws 2007 s 6 1, 2, 3). 
Apart from that, the licensing authority may at any time suspend or revoke a licence if there has been non-compliance of any provision of this by-law or a breach of any condition or restriction of the licence and failure of which shall be an offence and shall upon conviction be liable to a fine not exceeding two thousand ringgit or to imprisonment not exceeding one year or to both. ${ }^{37}$ In this case, the decision of the licensing authority shall be final. ${ }^{38}$ Moreover, any person who contravenes any of the provisions of these by-laws shall be guilty of an offence and shall upon conviction be liable to a fine not exceeding two thousand ringgit or to imprisonment for a term not exceeding one year or both fine and imprisonment and in the case of a continuing offence to a fine not exceeding two hundred ringgit for each day during which such offence is continued after conviction. ${ }^{39}$

Moreover, the same provision comprises in the Petaling Jaya City Council by-laws. As indicated if any person uses the word, logo or halal or be certified halal signage without a certificate of halal issued by the Islamic Development Department of Malaysia, the Selangor Islamic Council or any other relevant authority shall be guilty of an offence and shall upon conviction be liable to a fine not exceeding two thousand ringgit or to imprisonment not exceeding one year or both and if any person fails to produce the certificate upon request made by the licensing authority shall be guilty of an offence. ${ }^{40}$ In addition, at any time the licensing authority may suspend or revoke a licence if there has been non-compliance of any provision of this by-law or a breach of any condition or restriction of the licence and shall upon conviction be liable to a fine not exceeding two thousand ringgit or to imprisonment for a term not exceeding one year or both fine and imprisonment and in the case of a continuing offence to a fine not exceeding two hundred ringgit for each day during which such offence is continued after conviction. ${ }^{41}$

The abovementioned laws give local authority more enforcement power but they are focusing on other activities other than the execution of illegal halal activities.

\footnotetext{
37 S $12(1,2)$ Advertisement (Shah Alam City Council) By-Laws 2007).

38 Advertisement (S 12 (4) of Shah Alam City Council) By-Laws 2007).

39 S 37 of Advertisement (Shah Alam City Council) By-Laws 2007).

40 Advertisement (S 6 (1, 2, 3) of Petaling Jaya City Council, By-Laws 2007).

41 S 37 of Advertisement (Petaling Jaya City Council, By-Laws 2007).
} 


\section{PARLIAMENTARY DEBATES ON DEVELOPMENT OF HALAL CONCERNS}

The previous discussion is related to specific laws regarding halal; besides these, Parliament members have had some deliberation related to Shariah compliance, halal industry development, implementation of halal laws, etc. in the Parliament. This indicates how much halal issue is important in Malaysia and how apparent among the Parliament Members and government is taking halal matter seriously.

In March 2014 at the $13^{\text {th }}$ Senate parliamentary session, some honourable parliament members raised questions on halal matters. They argued that JAKIM's halal certificate should be expanded to all, on every consumer goods. The government, through JAKIM, has implemented halal certification scheme in seven areas. However, the application of halal certification in Malaysia in any field is voluntary. ${ }^{42}$ Furthermore, one honorable member ${ }^{43}$ wanted an explanation from JAKIM on how they can see the issued halal certificate and logo to ensure that the products are actually halal. In this same session, it was also raised that there were many problems faced by the Malaysian halal industry as there is no specific act to govern halal related matters. It was suggested that the government should look into this matter in a holistic manner so that it is not only in terms of halal food and drinks alone but halal also covers everything i.e. how the labels are legally used, how business and trade are operated; thus there is a need to focus on implementation of halal laws as well.

In another suggestion, the members of Parliament were of the opinion that JAKIM and JAIN have to continuously run comprehensive auditing of all restaurants and this also includes checking of various aspects such as the use of raw resources, preparation of food, cleanliness, staff, equipment, storage, transport and also restaurant or factory environment. The local government has the power to conduct periodic visits and auditing. JAKIM has already provided particular training. Hence, the local authorities should be more proactive in helping JAKIM and the State Religious Authority to implement halal regulations. Conversely, it was also pointed out that ${ }^{44}$ international franchise companies should also strictly comply with the Malaysian halal

42 Jamil Khir Baharom, 'No Halal Cert Does Not Mean Food is Haram,' https:// www.cljlaw.com/files/hansard, accessed on 18 April 2015.

43 Gerik Sabak Bernam, 'No Halal Cert Does Not Mean Food is Haram,' https:// www.cljlaw.com/files/hansard, accessed on 22 April 2015.

44 Madinah Tun Abang Haji Abdul Rahim, 'No Halal Cert Does Not Mean Food is Haram,' https://www.cljlaw .co m/files/hansard, accessed on 27 April 2015. 
requirements. It perceives that issues related to halal do not only concerned about the law but also its implementation, how it is regulated, the authorities who are authorized to exercise their power and so on.

\section{CONCLUSION}

The above discussion bears witness that to provide halal certificate and issues relate to halal, Malaysia has to expand its legal provisions. The laws are sufficient and have been developed from time to time and are applicable throughout the country. The TDA 1972 along with its order Trade Description (Use of Expression Halal) Order 1975 and the Trade Description (Making of Food) Order 1975 are the main legislations to govern halal issues. The amendments of TDA and TDO 2011 have brought main changes to the halal certification laws in this country. The Acts insert the specific provisions to administer halal issues and an order describes the procedure to deal with halal matters. Equally, JAKIM and MDTCC have also halal regulated power; by virtue of the said Act and are authorized to enforce halal issues. Still they have limitations in terms of effective execution of halal laws. Ostensibly they are separated but in reality, in terms of activities, they are quietly under the shadow of MDTCC. However, Act 2011 gives them the power to govern halal issues but they are not fully exercising the enforcement power. As a result, though Malaysia has enough laws, execution on halal issues is not developed properly.

Therefore, it is suggested that the halal governing authorities have to be more active in terms of implementing their power for the effective execution of halal laws. Without exercising their enforcement power, they cannot solve halal problems. In contrast, local authorities have halal execution power in their by-laws, they have specific sections to regulate halal issues. It is not possible for JAKIM and MDTCC to monitor all the areas but local authorities can help JAKIM and MDTCC to do it properly. This issue has also been discussed in Parliamentary sessions too. Members of the Parliament also point out that local authority can work with JAKIM for the effective implementation of halal certification. If they enhance their monitoring activities then halal food can be insured more than the present time. In this regard, the government can order local authorities to work with JAKIM to enforce the halal issues, thus they will be more cautious about their execution of halal enforcement. It may be perceived here that the laws regulating halal certification as they exist today in Malaysia are quite adequate to deal with halal matters. However, in the case of enforcement of halal laws, there will always be a need for some coordination of the authorities in terms of effective enforcement of halal issues to meet developing and often unexpected problems. 


\section{ACKNOWLEDGEMENTS}

The authors would like to express their humble gratitude to the honourable Professor Dr. Ida Madieha Abd. Ghani Azmi and Asst. Professor Dr. Noriah Ramli, Faculty of Law, International Islamic University Malaysia, for their intellectual assistance in the completion of this paper. Recognition is also given to the International Institute for Halal Research and Training (INHART).

\section{REFERENCES}

Aziz, N. A., Ibrahim, I., \& Raof, N. A., 'The Need for Legal Intervention within the Halal Pharmaceutical Industry,' Procedia-Social and Behavioral Sciences (2014): 121-132.

Che Omar, C. M. Z., 'Challenges and Marketing Strategies of Halal Products in Malaysia,' Interdisciplinary Journal of Research in Business, 3/2 (2013): 11-17.

Department of Islamic Development Malaysia, 'About JAKIM,' http://www. islam.gov.my/en/about-jakim, accessed on 24 February 2015.

Department of Islamic Development Malaysia, 'History of JAKIM,' http:// www.islam.gov.my/en/about-jakim/jakim-s-profile/history, accessed on 27 February 2015.

Department of Islamic Development Malaysia, 'Manual Procedure for Malaysia Halal Certification (Third Revision) 2014,' Halal Malaysia Official Portal, http://www.halal.gov.my, accessed on 20 October 2015.

Department of Islamic Development Malaysia, 'The Role of JAKIM,' http// www.islam.gov.my, accessed on 15 October 2015.

Department of Islamic Development Malaysia, 'Vision, Mission, Objectives, Functions,' http://www.islam.gov.my/en/about-jakim/vision-missionobjectives-functions, accessed on 02 March 2015.

Gerik Sabak Bernam, 'No Halal Cert Does Not Mean Food is Haram,' https:// www.cljlaw.com/files/hansard, accessed on 22 April 2015.

Global Islamic Finance Report, 'The Global Halal Industry: An Overview,' http://gifr.net/gifr2013/ch_13.PDF, accessed on 20 February 2015.

Halal Hub Division of JAKIM, 'Halal History,' http://www.halal.gov.my, accessed on 27 February 2015).

Halal Hub Division of JAKIM, 'Halal Malaysian Procedure Manual,' http:// www.halal.gov.my/v4/index.php/my/garis-panduan/manual-prosedurpensijilan-halal-malaysia, accessed on 28 February 2015). 
Jamil Khir Baharom, 'No Halal Cert Does Not Mean Food is Haram,' https:// www.cljlaw.com/files/hansard, accessed on 18 April 2015.

Madinah Tun Abang Haji Abdul Rahim, 'No Halal Cert Does Not Mean Food is Haram,' https://www.cljlaw .com/files/hansard, accessed on 27 April 2015.

Ministry of Domestic Trade and Consumer Affairs, 'Background Information,' Official Portal of Ministry of Domestic Trade and Consumer Affairs, http://www.kpdnkk.gov.my, accessed on 10 October 2015.

Ministry of Domestic Trade, Cooperatives and Consumerism, 'Main Statistic of Enforcement 2010-2013,' http://www. kpdnkk.gov.my, accessed on 23 February 2015.

Ministry of Domestic Trade, Cooperatives and Consumerism, 'Minister's Strategic Thrusts,' http://www.kpdnkk.gov.my, para 1, accessed on 23 February 2015.

Ministry of Domestic Trade, Cooperatives and Consumerism, 'Ministry Profile,' http://www.kpdnkk.gov.my, accessed on 21 February 2015.

Ministry of Domestic Trade, Cooperatives and Consumerism, 'The Ministry Establishment,' http://www.kpdnkk.gov.my/index.php/en/mdtcc/profile /background, para 1, accessed on 19 February 2015.

Ministry of Urban Wellbeing, Housing and Local Government, 'About MHLG,' http://www.kpkt.gov.my/, accessed on 22 March 2015.

Muhammad, N. M. N., Isa, F. M., \& Kifli, B. C., 'Positioning Malaysia As Halal-Hub: Integration Role of Supply Chain Strategy and Halal Assurance System,' Asian Social Science, 5/7 (2009): 44.

N.a., 'Local Government Laws in Malaysia,' https:/www.scribd.com/ doc/14050520/Local-Government-Malaysia, accessed on 21 March 2015.

Nor Ain Musa, 'A Study on Muslim Consumers' Awareness on JAKIM Halal Logo,' (PhD Dissertation, Faculty of Engineering Technology, Universiti Malaysia Pahang, 2013).

Willy Adela Megan, 'The Edge Financial Daily', http://www.theedgemarkets. com/article/malaysia-seen-potential-\%E2\%80\%98halal-industrychampion\%E2\%80\%99, accessed on 7 March 2017.

Zannierah Syed Marzuki, S., Hall, C. M., \& Ballantine, P. W., 'Restaurant Manager and Halal Certification in Malaysia,' Journal of Foodservice Business Research, 15/2 (2012): 195-214. 


\section{Statutes}

Advertisement (Petaling Jaya City Council) By-Laws 2007 (Malay.)

Advertisement (Shah Alam City Council) By-Laws 2007. (Malay.)

Halal Product Certification Act (2014).Act No.33

Local Government Act, 1976 (Malay.)

The Malaysian Halal Certification Procedure Manual, 2014 (Malay.)

Trade Description (Certification and Marking of Halal) Order 2011 (Malay.)

Trade Description (Definition of Halal) Order 2011 (Malay.)

Trade Description Act 1972 (Malay.)

Trade Description Act 2011 (Malay.)

\section{Interviews}

Othman Nawang (Deputy Director of Enforcement Division, Ministry of Domestic Trade, Cooperatives and Consumerism), in interview with author, 5 October 2015.

Mohd. Amri Abdullah (Senior Assistant Director, Halal Hub Division, Department of Islamic Development Malaysia), in personal communication with author, 13 February 2015. 
Jurnal Syariah, Jil. 26, Bil. 1 (2018) 141-166 